\title{
TEORIA DO ESTADO COMPOSTO
}

\author{
José Nicolau dos Santos \\ Professor nas Faculdades de Direito e de Filosofia \\ da Universidade do Paraná.
}

\section{A CRISE DOS DOGMAS JURÍDICOS}

Há no moderno Direito Público uma aguda e generalizada crise conceitual. Crise no conceito de Estado, crise no conceito de Soberania, crise no conceito de Regime, crise no conceito de tôdas as noções básicas sôbre as quais desejam os vários sistemas jurídicos alimentar raciocínios e derivar conclusões. Os sentidos clássicos de Liberdade, Democracia, Justiça, Ordem, Constituíção e mesmo dos vocábulos Direito e Lei são hoje conceituações tão maleáveis e frágeis, idéias tão dúbias e inconstantes que, prévia e necessàriamente, deverão ser definidas por quem as deseja manipular e aplicar. Há, pois, motivo de crer na sábia ironia de Platão quando advertiu: "Se evitas preocupar-te com a questão de nomes, muito mais rico serás em sabedoria".

A crise do Direito Público atual começa pela concepção ainda flutuante e equívoca que fazemos da natureza do Estado - ora como fato ou realidade histórica, ora como norma ou ordenamento jurídico, ora como valor ou condicionamento ético - e termina pela interpretação não menos equívoca e flutuante que conjeturamos a propósito da finalidade do mesmo Estado, das suas funções, dos seus objetivos, das suas compe- 
tências. Assim, tem razão em assegurar Del Vecchio: "Que o Estado Moderno está em crise... é uma verdade com tal frequência repetida que já se tornou um lugar comum". (1)

Mas a palavra crise também merece aqui uma compreensão apropriada: não se casa com a sinonimia figurada de declínio ou involução, de naufrágio ou fracasso, de conjuntura perigosa ou anormal. Significa, na melhor filiação etimológica do grego krisis, apenas julgamento. Quando afirmamos de início que o Direito Público penetrou em uma fase acentuadamente crítica, pretendemos ressaltar que todos os seus dogmas merecem uma urgente revisão de valores, um reajustamento imediato de conceitos, afim de que a Ciência Política não permaneça estagnada, tolhida, quase incapacitada de assimilar os novos fatos histórico-jurídicos que inevitàvelmente vão surgindo na vida e desenvolvimento do Estado Moderno.

\section{OS PROBLEMAS DA MORFOLOGIA POLÍTICA}

Para o Direito Público atual, nenhum problema transparece mais comum e dificultoso do que a busca de novos critérios para a catalogação, suficientemente precisa e satisfatória, das formas estatais que se vão desenhando, com espontânea profusão, na época em que vivemos. A Comunidade Britânica, a União Soviética, a antiga Sociedade das Nações, a recente Organização das Nações Unidas, enfim a União Francesa de 1946, constituem por certo associações político-administrativas cujas estruturas desafiam fácil e rápida inclusão nas categorias morfológicas que herdamos do passado século. E', pois, imperioso e urgente para a Ciência Política encontrar um criterium de classificação dos Estados que determine as semelhanças genéricas e as diferenças específicas das referidas organizações. Pela sua multiplicidade, já não satisfaz ao jurista e ao histo-

(1) Giorgio Del Vecehio - Crisis del Derecho y Crisis del Estado - Madrid, 1935. 
riador vê-las descritas simplesmente como formas federativas sui-generis, isto é, excecionais ou anômadas.

Com razão já prenotou Carré de Malberg haver a Teoria Geral do Estado nascido e vicejado na contemplação do Estado Unitário e soberano. De fato, para Maquiavel, Bodin, Dante, Montesquieu, Hobbes ou Rousseau - que são os mais próximos e mais lembrados precursores desta ciência - o Estado estava unido e confundido na pessoa física e soberana do Monarca. "L'État c'est moi", dizia Luis XIV.

Unidade e soberania são idéias correlatas na velha concepção estatal. Pelo conceito monárquico de Bodin (1572) ou pela definição republicana da Constituição Francesa de 1793 (art. 25), "a soberania reside no povo; ela é una e indivisível, imprescritível e inalienável".

Muito simples, portanto, o critério da classificação dos Estados Unitários, lá pelas éras dos Luises de França ou dos Stuarts ingleses. Êsse critério, unívoco e incontroverso, já estava escrito nas primeiras linhas de "O Principe", assegurando Maquiavel: "Tutti gli Stati o sono repubbli.he o sono principati".

As próprias repúblicas históricas, as mais antigas como a de Roma ou as mais recentes como a de Veneza, tinham ainda o cunho de nobreza e aristocracia, oscilando entre a preponderância da classe patrícia e a soberania de seus cézares e doges. As primeiras dificuldades para o conceito e a classificação morfológica dos Estados modernos surgem quando, no "Contrato Social", revolucionário e ardente, Rousseau, doutrinàriamente, retira o poder soberano da corôa real e com ela presenteia o povo. Mas ainda não subverte o conceito clássico e bodiniano da palavra "soberania", pois nas "Lettres écrites de la montagne" continua a afiançar: "Em todo Estado político é necessário uma fôrça suprema, um centro para onde tudo convirja, um princípio de onde tudo derive, un souverain qui puissa tout".

Ora, na atualidade, o conceito de soberania absoluta, de poder político supremo e incontrolável, de fôrça estatal necessária é irresistível, é idéia superada, inoperante. Na ordem jurídica internacional há direitos superiores ao Estado, na ordem interna e constitucional há também direitos individuais e 
sociais que são reconhecidos como anteriores e, consequentemente, superiores ao Estado. A doutrina do "pluralismo jurídico" de Laski, Gurvitch ou de Maritain (2) não deixa dúvidas a êsse propósito. E a "Declaração Universal dos Direitos do Homem" proclamada em 1948 pela assembléia da ONU, em $\mathrm{Pa}-$ ris, é uma confirmação da anterioridade e supremacia dos direitos naturais do homem sôbre o próprio Estado, que os deve tutelar e garantir obrigatòriamente, consoante já evidenciara Mirkine Guetzéwitch. (3) Como, pois, falar ainda de soberania estatal irrestrita? Como tornar êsse conceito, em declarada crise, para classificar as entidades políticas no velho esquema ainda repetido: Estados soberanos, Estados semi-soberanos (expressão que encerra uma contradição) e Estados vassalos?

\section{A ERA DO ESTADO COMPOSTO}

Outras dificuldades que tumultuaram a morfologia estatal contemporânea referem-se à emersão intensa das novas tendências federais e confederais, com aspectos incomuns e impre-

(2) Jacques Maritain - O Homem e o Estado - Rio 1952, pág. 55, escreve: "O Estado não é e nem jamais foi autênticamente Soberano. 0 povo também não é Soberano. Por sua vez Machado Paupério (O conceito polêmico de Soberania - Rio, pág. 164) opina: "O Estado não é criador arbitrário do Direito, a sua soberania não pode, por conseguinte, ser ilimitada. Enfim Brown Scott (El progresso del Derecho de Gentes) assevera também: "Porque tratar de limitar a Soberania quando esta Soberania é cousa inexistente?"

(3) Mirkine Guetzéwitch - As novas tendências do Direito Constitucional - São Paulo, 1933 - pág. 179, diz: "Colocar os direitos do homem e do cidadão sob a garantia do Direito Internacional, estabelecer a proteção internacional dos direitos do homem, eis o verdadeiro ideal humanitário que tende a fazer do homem ử verdadeiro cidadão do mundo".

E Levi Carneiro - O Direito Internacional e a Democracia - Rio, 1945 - pág. 37 , acrescenta: "Na mesma ordem de idéias, Lapradelle, no projeto de Declaração dos direitos e deveres das Nações, apresentado, em 1921, ao Instituto de Direito Internacional, declarava que o objetivo social do Direito Internacional é a defesa dos direitos do homem: - Os Estados têm deveres em relação, não sòmente aos outros Estados, mas também em relação aos homens - como o de respeitar suas vidas, a sua liberdade, as suas crenças". 
vistos. O fenômeno federativo é certamente velho. Podemos considerá-lo mesmo como sendo uma das mais antigas e persistentes causas do crescimento e evolução das sociedades políticas, Scelle definiu muito bem o Estado como sendo "uma ordem jurídica de superposição" (4) atendendo, assim, à sua formação estrutural, decorrente de aglutinações espaciais e demográficas constantes. Violenta ou pacìficamente, a História nos mostra os Estados cresceram por anexações ou alianças e também como distenderam o raio de sua jurisdição através de processos administrativos centralizadores. Podem variar os casus foederis, neles se incluindo mesmo a "aglutinação dos espaços crescentes" que, através de um falso determinismo telúrico, já foi erigido em postulado ambicioso para uma Realpolitik de Bismark ou para uma Geopolitik de Ratzel, Kejellen ou Haushofer. (5) Pontes de Miranda nos lembra, com expressiva metáfora, da fome de poder e de expansionismo territorial que não ocultam certos "Estados devoradores", procurando, além, estatuir a lei sociológica da "crescente integração dos círculos sociais".

(4) Fustel de Coulanges - A Cidade Antiga - Lisboa 1950 - Vol. I, pág. 184, noticia: "Família, fratria, tribo, cidade são sociedades perfeitamente análogas e nascidas umas das outras por uma série de federações... Em religião, substituiu grande quantidade de 'pequenos cultos, acima dos quais se estabeleceu o culto comum. Em política continuou a funcionar uma infinidade de pequenos governos, e acima dos quais se colocou o govêrno comum".

Georges Scelle - Le Droit Public et la Théorie de l'état - in Introdution a l'étude du Droit - Paris, 1951, Vol. I, pág. 75 - justifica e esclarece: "O Estado é, com efeito, uma ordem jurídica de superposição... A ordem jurídica do Estado é uma ordem jurídica composta, superpondo-se a tôdas as outras ordens jurídicas dos grupos descentralizados, federalizados, associados, colonizados, etc., que constituem a comunidade sob sua dependência".

(5) Hans W. Weigert - Geopolítica - México, 1943, pág. 241, nos informa: "O Lebensraum da geopolítica de Haushofer é o mundo inteiro". Delgado de Carvalho, em artigo escrito para a Revista Brasileira de Geografia - n. ${ }^{\circ}$ 3, 1939, págs. 104 a 109 - também observa: "Com Ratzel aparecem novidades: à noção de extensão se substitui a noção humana de espaço - o Raum. A confusão dos têrmos permite tirar maior número de argumentos. 0 espaço vital e justificação de muitas reinvidicações".

Acreditamos que o living-space de que a Geopolítica faz pedra angular de seus propósitos pseudo-científicos (ela não é uma Geopo- 
Dêsse fenômeno federativo, mais histórico do que jurídico, surgiu a crise morfológica do antigo e puro Estado unitário, tão fàcilmente identificável pela sua forma de govêrno (os principados e repúblicas, de Maquiavel) ou pelos seus diferentes regimes políticos, que Aristóteles bem distinguiu em monarquias, aristocracias e democracias. Agora, ao lado das formas de govêrno vão aparecer, clara e especìficamente caraterizadas, as formas do Estado. Num trabalho lento de observação e comparação os constitucionalistas de maior fama conseguiram fixar e definir certos tipos predominantes, que denominaram de Estados simples ou unitários contrapostos aos Estados compostos ou unidos, nêste grupo incluindo as Federações, as Confederações, e as Uniões de Estados, enfim, subdivididas em Uniões pessoais, reais e incorporadas.

Durante muitos decênios, serviu esta classificação ao Direito Público, senão incontroversa, pelo menos sem muitos opositores. Mas enquanto a Federação foi considerada pelos juristas como um verdadeiro Estado composto, a Confederação desmereceu consagração equivalente. Foi esta dúvida que reavivou o debate sôbre a imperfeita classificação das formas de Estado.

\section{FEDERAÇÃO E CONFEDERAC̣ÃO}

A distinção sutil, o colorido leve que marca a diferença essencial entre o Estado Federal e a Confederação de Estados (inclusos no gênero dos Estados Compostos) sempre residiu no antigo e uniforme conceito de soberania que a Revolução Francesa herdou de Bodin e transmitiu ao Direito Constitucional do futuro. Assim, pois, segundo êsse velho critério, todos os Es-

litik, mas na verdade uma Wehr-Geopolitik) é uma antítese absoluta do fenômeno federativo. Êste também pode determinar algumas vêzes a ampliação da área geográfica do Estado (Stelle), e dar-lhe um maior espaço de vida política e econômica (Raum), porém, dá e assegura as condições jurídicas de igualdade entre as nacionalidades que une. As máximas. violentas da Geopolítica ("o dobre de finados dos pequenos Estados", como já disse George Kiss não pregam a união, mas sim a subordinação absoluta, ou melhor, a absorção completa, imperialista e colonial, de outros territórios e populações. 
tados que se uniam, mas guardavam intacta para si a sobercnia, isto é, aquêle "poder absoluto de ditar leis" a que aludira Bodin, deviam formar em conjunto uma Confederação. Os Estados que se uniam guardando apenas relativa autonomia interna, mas delegavam à União a maior parcela dos seus poderes soberanos, constituiam, com o rigor da expressão, um Estado Federal. Só a êste cabia a personalidade internacional, como verdadeiro Estado-síntese.

Contudo, resistindo ao esfôrço dos escritores antigos e modernos que buscaram elucidar as diferenças fundamentais entre a Federação e a Confederação, os traços distintivos entre elas persistem obscuros e imprecisos. Lapradelle, como Delbez ou Darcy Azambuja procuram caraterizar os dois tipos numa hábil sequência de minúcias estruturais. Lafayette, Jellinek ou Wilson preferem, ao contrário, reduzir tôdas as diferenciações mínimas e insignificantes a um sinal único, mais visível, mais constante e expressivo, qual seja a fonte jurídica do fenômeno federativo.

Assim, pois, o mestre alemão traçou a definição clássica de Confederação alicerçando-a num pacto internacional e diz textualmente que ela é "a união permanente e contratual de Estados independentes, com o fim de defender o território comum e assegurar a paz interior". (6) Woodrow Wilson, por sua vez, preceitua: "A Confederação era composta de Estados e só a sua lei constitucional era um tratado" (7). Enfim Lafayette esclarece mais ampla e precisamente: "A Federação estabelece-se, não por tratados, mas por ato constitucional, do domínio do Direito Público Interno e não do Direito Internacional" (8).

Numa revisão histórica Pedro Calmon oportunamente ensina que as Confederações "lembram as anfictiônias ou alianças pan-helênicas... um super-govêrno, a cujo comando se sub-

(6) Georg Jellinek - Teoria General del Estado - Buenos Aires, 1943, pág. 616 .

(7) Woodrow Wilson - L’État - Paris, 1902, Vol. II, pág. 335.

(8) Lafayette Rodrigues Pereira - Direito Internacional - Rio 1902, Vol. I, pág. 66 . 
metiam. A diferença está na duração. As anfictiônias eram provisórias... a confederação é perpétua”. (9)

Para alguns tratadistas as Confederações não existiram na antiguidade e já não perduram na época atual. Maurice Hauriou focaliza os tipos puros de Estados confederados que a História registrou, acrescentando: “Atualmente já não existem Confederações. Estas organizações são instáveis, pois se dissolvem ou se transformam em Estados Federais". Tais foram, realmente, os exemplos dados pelos Estados Unidos .... (1777-1787), pela Suiça (em 1848) pela Confederação Germânica (1815-1866) e pela Confederação da Alemanha do Norte, criada pelo Tratado de Praga (1866) e enfim diluida no Império Federal Alemão de 1871.

Muitos autores acreditam que êstes, e só êstes, foram os tipos puros de Estados confederados. Contudo, Hauriou amplia o conceito confederal quando reconhece formas análogas em períodos antigos, escrevendo: "Existiram na História muitas Confederações, desde a Liga Aquéa, na Grécia, até a Confederação das Cidades Latinas, da qual participou Roma". E bem elucida o professor de Toulouse a irresistível tendência federativa já manifesta na antiguidade: "A Cidade-Estado é simultâneamente um refúgio fortificado e um mercado, um oppidum e um emporium... Porém, o oppidum não explica por completo a cidade antiga. Falta nêle um elemento essencial que é a federação. Todo Estado é federativo e a cidade antiga é o resultado de um sinecismo, isto é, da federação de vários oppida. 0 rei da cidade antiga foi um rei de reis, porque conseguiu se sobrepor aos chefes dos oppidas, assim como o rei moderno colocou-se sôbre os barões feudais" (10) Também Maritain evidencia que "nos tempos feudais, o rei era apenas o Suserano dos Suseranos, cada um dos quais possuia seus próprios direitos e poderes". (11) Mas o mesmo Hauriou, alargando o conceito

(9) Pedro Calmon - Curso de Teoria Geral do Estado - Rio, 1949, pág. 224.

(10) Maurice Hauriou - Derecho Público y Constitucional - Ed. Reus, Madrid, págs. 368, 40 e 41.

(11) Jacques Maritain - Op. cit., pág. 48. 
de Confederação para tempos remotos, opõe-se a que as novas formas anfictionais modernas penetrem naquela categoria. $\mathrm{Pa}-$ ra êle, a velha Sociedade das Nações, por exemplo, não constituia uma Confederação de Estado. Entretanto, contra a sua opinião, erguem-se no momento altos cultores do Direito Público, como Fischbach, Kraus ou Verdross que viam na SDN uma Confederação, da mesma maneira em que também é vista a moderna Organização das Nações Unidas por Redslob, Delbez e outros.

Diante da discordância aberta entre os mestres, qualquer preocupação de enquadrar as novas formas estatais numa classificação geral e metódica depende, como já alertou Spiroupoulos, de dar maior plasticidade às categorias tradicionais principalmente à Confederação ou, então, criar outras mais adequadas.

\section{A INSUFICIENCIA DOS CONCEITOS}

Antes de proseguirmos na análise de moderníssimas estruturas políticas, tais como a ONU, a União Francesa, a União Rússa e o Império Britânico, convém recordar os conceitos mais expressivos que se fizeram caraterizadores de algumas modalidades de Estados compostos.

Darcy Azambuja define a Federação ou Estado Federal como sendo "um Estado formado pela união de vários Estados, que perdem a soberania em favor da União Federal, a qual aparece assim no Direito Internacional como um Estado simples". (12) Por sua vez Queiroz Lima conceitua: "Estado Federal é um Estado formado pela união de vários Estados, é um Estado de Estados - Staatenstaat - segundo a expressão dos alemães". (13) E explica ainda o mesmo tratadista: "O que carateriza o Estado Federal é justamente o fato de, sôbre um mesmo território e sôbre as mesmas pessoas, se exercer, harmônica

(12) Darcy Azambuja - Teoria Geral do Estado - Pôrto Alegre, 1942, pág. 294.

(13) Queiroz Lima - Teoria do Estado - Rio, 1939, pág. 279. 
e simultâneamente, a ação política de dois governos distintos, o federal e o estadual". Por isso afiança Hauriou que o Estado Federal "é uma sociedade de Estados que constitui um Super-Estado". Curioso notar que, sob ângulo de sua origem histórica, o laço federativo tanto se pode formar por uma tendência de agregação de Estados, a exemplo dos Estados Unidos da América (1775-1787), como também por um movimento de segregação, como no caso do Brasil, que desde 1889 deixou de ter a forma de Império Unitário para assumir a de uma República Federal.

A Confederação de Estados é definida por Fischbach em têrmos muito semelhantes aos de Jellinek: "é a associação de caráter permanente e orgânico de vários Estados independentes com objeto de protejer-se mùtuamente na ordem interior $\mathrm{e}$ exterior e de realizar também outros fins pertencentes ao setor da administração do Estado". (14) Por esta e outras definições construídas, permanecem as dúvidas se a Confederação realmente constitui um verdadeiro Estado composto, como acontece com a Federação. Eis o motivo de nos afirmar, com razão, Spiropoulos: "Todos estão de acôrdo em considerar a Confederação de Estados como uma união de Direito das Gentes (qualificação dependente da aceitação de definições correspondentes) mas a dificuldade reside em formular a definição exata desta formação jurídica. Dêste modo torna-se hábito confrontar a Confederação de Estados e o Estado Federativo, fazendo assim ressaltar os traços caraterísticos dessas duas entidades jurídicas". (15) Seguindo êsse método e auscultando analogias, Malberg explica: "Uma federação entre Estados pode realizar-se sob duas formas: a Confederação de Estados e o Estado Federal. Em ambos os casos há uma formação e um laço federativo. Nos dois casos também os Estados confederados concorrem para a formação da vontade central. A pesar

(14) Oskar Georg Fischbach - Teoria General del Estado - Barcelona, 1949 ,pág. 171.

(15) Jean Spiropoulos - Théorie Generale du Droit International, Paris, 1930, pág. 155. 
disso existe entre essas duas classes de formações federativas uma diferença fundamental que surge de suas próprias denominações. Uma é qualificada tão sòmente de Confederação de Estados, outra tem o nome de Estado Federal. A terminologia alemã é igualmente significativa: por um lado Staatenbund quer dizer laço federativo entre Estados confederados, por outro Bundesstaat traduz Estado que deriva de uma federação, portanto Estado distinto dos Estados confederados e a êles superposto." (16) C.omo tantos outros autores, também o tratadista francês opina em que a essencial diferença entre uma e outra formação política descansa na relação contratual que une os membros de uma Confederação, enquanto "o Estado Federal, pelo contrário, como todo Estado está fundado sôbre a sua Constituição".

E' de se convir em que as diferenciações assim exemplificadas seriam plenamente satisfatórias, no campo da filosofia política se, acaso permanecessem incontroversos os conceitos de Estado e de Constituição. Mas ambos foram também atingidos pela ampla krisis conceitual do moderno Direito Público. A Confederação - alega-se - não constitui um Estado. Mas que é Estado? Se não é êste um momento próprio de alongar uma digressão a propósito, lembremos ao menos o desalento de Rehm alegando que o Estado, como "conceito fundamental", não pode ser definido. Recordemos a indecisão de Maciejewski ponderando existirem tantas definições de Estado quantos pensadores sôbre êle escreveram. Invoquemos a dúvida de Brown Scott quando a si mesmo pergunta: "Isso que se chama Estado, existe realmente?" (17) Citemos o humorado, mas exato, pronunciamento de Scelle: "Dar uma definição de Estado é, em Direito Público, uma espécie de quadratura do círculo, pois devemos declarar que nenhuma definição de Estado é cientìficamente satisfatória: ela não poderá ser senão uma definição histórico-política e empírica”. (18)

(16) R. Carré de Malberg - Teoria General del Estado - México, 1948, pág. 100.

(17) James Brown Scott - El progresso del Derecho de Gentes - Madrid, 1936 , pág. 58.

(18) Georges Scelle - Op. cit., pág. 73. 


\section{QUE E UMA CONSTITUIÇÃO?}

Não menos flexível e polêmico é o conceito de Constituição. O Estado Federal, ensina-se, é cimentado numa Constituição. Mas que é uma Constituição? Hermann Heller (19) penetrando a sua análise, desvenda nada menos de cinco conceitos distintos. Friedrich vai além e nos desdobra seis conceitos inconfundíveis.

Pedro Calmon procura imprimir maior simplificação ao assunto: "Constituição é o corpo de leis que rege o Estado, limitando o poder do govêrno e determinando a sua realização. A expressão é tomada em dois sentidos, material e formal. Dizemos material, quando a apreciamos como conjunto das insti-

(19) Hermann Heller - Teoria del Estado - México, 1947, pág. 277 admite dois conceitos sociológicos de Constituição ou conceitos científicos-reais e três conceitos jurídicos ou formais que são: I) "a estrutura característica do poder", II) "a estrutura relativamente permanente da unidade estatal" - III) "situação jurídica total do Estado", IV) "um conteúdo parcial extraído da ordenação jurídica total do Estado, mas valorizado como essência ou ordenação fundamental", V) "a totalidade dos preceitos jurídicos fixados por escrito no texto constitucional". Êste último corresponde ao conceito de Constituição formal.

Por sua vez Friedrich apresenta seis conceitos, que em ampla síntese serão:

I - Conceito filosófico (ou total) aceito no sentido de Rousseau ou Coke: "a Constituição é uma concepção geral da vida", plasmada em normas.

II - Conceito estrutural (sociológico e até biológico) prevista por Aristóteles que considerava a politéia (constituição) como sendo "o estado de cousas de uma Cidade".

III - Conceito jurídico (compreensão sistemática-normativa), isto é, "a essência da ordenação fundamental do Estado".

IV - Conceito documental (aspecto formal) esclarecendo a necessidade do texto escrito, consoante Lassale que via a Constituição como "um documento; sôbre uma folha de papel, contendo tôdas as instituições e princípios de govêrnos de um país".

V - Conceito de procedimento (aspecto ideológico) que segundo Friedrich "caracteriza-se por encerrar um procedimento democrático ou popular de reforma".

VI - Conceito funcional (técnica política) que ainda conforme Friedrich representa "o estabelecimento e manutenção de restrições ao poder político e à ação governamental". (Carl J. Friedrich - Teoria y realidad de la organización constitucional democrática - México, 1946, pág. 123/5.) 
tuições políticas de um país. E' formal, na accepção do documento que define e regulamenta esas instituições". (21)

Também Jellinek distingue a Constituição sòmente neste duplo sentido: como ser e como dever ser, ou seja, como estrutura (sentido material) e como direito, correspondendo ao sentido formal.

Ora, lembrando aqui a doutrina dos mestres antigos e modernos, o que desejamos colocar em evidência é apenas êste fato: qualquer associação política de tipo federal ou confederal há-de forçòsamente possuir a sua Constituição, tanto no lato sentido material ou de estrutura, como no estrito sentido formal ou de estatuto jurídico, quer ainda esta Constituição seja uma lei ou um contrato. A Carta de São Francisco, por exemplo, como tratado internacional é ao mesmo tempo contrato multilateral e lei constitucional da ONU. Não ficam, portanto, implìcitamente derimidas as diferenciações entre o Estado Federal e a Confederação de Estados com as simples afirmativas de que a primeira categoria morfológica lastra-se numa Constituição e a segunda num pacto.

Muito expressiva é a opinião de Scelle: "Não se pode admitir, por certo, o critério inteiramente formal da origem da competência do govêrno federal que seria uma Constituição, enquanto para a Confederação repousaria num tratado, porque ambos revelam o mesmo conteúdo material. Este conteúdo é constituido pelas normas de partilha inter-governamental, com a simples diferenciação de mais ou de menos" (22) Para Scelle o melhor critério está nítido na "competência internacional", que é imediata para os Estados confederados e mediata para os federados.

Kranenburg por sua vez opina que "o melhor critério para diferenciar um Estado Federal e uma Confederação reside em responder à pergunta: - os cidadãos de um Estado membro

(21) Pedro Calmon - Op. cit., pág. 259.

(22) Georges Scelle - Cours de Droit International Public - Paris, 1948, pág. 271. 
são ou não afetados diretamente pelas leis emanadas dos orgãos legislativos da entidade composta? Em um Estado Federal os orgãos centrais possuem direitos e obrigações diretos em relação aos cidadãos, enquanto em uma Confederação os direitos e obrigações daquêles órgãos incidem sôbre as suas partes constituintes (Estados membros) e não sôbre os cidadãos".

Neste particular julgamos ainda assistir tôda razão a Kelsen quando assevera não existir dissemelhanças fundamentais entre a Federação e a Confederação além das que são marcadas pela maior ou menor descentralização de poderes políticos e administrativos. A lição do professor de Viena é, aquí, insinuante e clara: "O Estado Federal corresponde, simplesmente, a um certo tipo de descentralização, nenhuma diferença de princípio o separa da Confederação de Estados. Esta só dêle se distingue por uma descentralização mais acentuada".

\section{CONCEITO DE ESTADO PROTEGIDO}

A teoria do "Estado composto" não colide sòmente com o problema árduo de distinguir especificamente a natureza íntima do Estado Federal e da Confederação de Estados. Os casus foederis vão além, criando associações políticas irredutiveis às formas precedentes. Diz bem Spiropoulos: "Sob a epígrafe de Uniões de Estados, no sentido mais lato, pode-se entender a união de dois ou mais Estados por laços jurídicos... A definição dos traços caraterísticos das diferentes uniões é, quase sempre, acompanhada de dificuldades consideráveis". (25)

Kelsen coloca sob o título genérico de "Uniões de Estados", (Staatenverbindungen) diversas formas típicas e já consagradas pela História e pela doutrina: o Protetorado, as Uniões (Unionen) pessoais e reais, enfim a Comunidade Jurídica In-

(23) R. Kranenburg - Teoria Política, México 1941, pág. 160.

(24) Hans Kelsen - Teoria Geral do Estado - Coimbra, 1945, pág. 91.

(25) Jean Spiropoulos - Op. cit., pág. 15. 
ternacional, como sejam a velha SDN ou a atual ONU. Convém conceituar cada uma dessas formações político-jurídicas, atendendo o ensino dos mestres:

Para Kelsen, "chama-se protetorado a uma união entre dois Estados, em que um dêles - o Estado protetor - se obriga, para com o outro, a protege-lo internacionalmente, em especial contra ataques de terceiros Estados, renunciando o Estado protegido, em troca, ao exercício de certas funções". E acrescenta: "Por essa razão, chama-se ao protetorado união não-partidária, para distinguir, por exemplo, da União real, com a qual, no mais, tem muitas semrelhanças". (26)

Antes de ser instituida a atual União Francesa (1946), já prevenia Hauriou: "Por mais que o Protetorado não suponha anexação territorial, não se devem considerar as relações de proteção como relações de Direito Internacional e sim como de Direito Público Interno... Em suma, os Protetorados são partes do Império Colonial". (27) Realmente a França contou com vários exemplos nêsse sentido: o Protetorado de Anão, Tonquim, Laos (Tratado de 1874), Cambodge (1863), Tunísia (1881), Marrocos (1912), etc.

Como Hauriou, também Anzilotti e Spiropoulos acreditam que "o Protetorado não é uma instituição de Direito Internacional", mas "simples designação empregada para qualificar uma situação jurídica determinada". (28) Mas em visível oposição situam-se Kelsen e Fischbach, dizendo êste que "os Protetorados são relações de dependência internacional, tendo como nota caraterística a falta de igualdade dos Estados associados". (29) E Kelsen acentua: "as funções do Estado protetor

(26) Kelsen - Op. cit., pág. 99.

(27) Hauriou - Op. cit., pág. 367.

(28) Spiropoulos - Op. cit., pág. 159.

(29) O. Fischbach - Op. cit., pág. 169. 
referem-se, especialmente, à política externa do Estado protegido, que êle representa em tôdas as relações internacionais". (30)

Como se pode deduzir, o Protetorado é uma formação política que os internacionalistas relegam para a órbita do Direito Público Interno, enquanto os teoristas do Estado se esforçam para joga-la no campo do Direito das Gentes. Permanece, assim, numa espécie de zona neutral, de terra de ninguém, aguardando que o futuro lhe oferte ingresso definitivo em um dêsses dois ramos jurídicos.

Aplainando maiores dificuldades, Santi Romano procura resolver, com transigência eclética, a discórdia arguída. Distingue em princípio dois tipos de Protetorados: I) o tipo que constitui uma "união internacional", II) o tipo que constitui uma "união não-internacional". Relaciona o jurista italiano, como exemplo elucidativo do primeiro tipo, o Protetorado exercido pelo Reino da Itália sôbre a República de São Marinho (encravada no seu território) porque, conforme a Convenção de 1939, "essa proteção não implica nenhuma inferência na política do Estado protegido". Também os antigos Mandatos da classe A (Art. 22 do Tratado de Versalhes) e vários territórios sôbre tutela (Art. 75 etc. da Carta de São Francisco) são outros exemplos de Protetorados que formam uma "união internacional". O segundo tipo de Protetorados, representando a chamada "união não-internacional", tem para Santi Romano excelente expressão no "Protetorado Colonial", do qual nos oferece idéia precisa a formação imperial da Inglaterra, onde Nigéria, Uganda, etc., são seus protetorados coloniais na África. (31)

Mas nêste sentido prenota Accioly: "O Protetorado Internacional não se deve confundir com os chamados Protetorados Coloniais, que são meros artifícios pelos quais alguns países

(30) H. Kelsen - Op. cit. Também Lafayette (Op. cit. Vol. I, pág. 68) é de idêntico parecer, dizendo claramente: "O Protetorado tem por título o tratado celebrado entre o protegido e o protetor. E' à luz dêsse tratado que se pode caraterizar a posição do Estado protegido diante do Direito Internacional".

(31) Santi Romano - Diritto Costituzionale Generale - Milão 1947, pág. $133 / 8$. 
colonizadores tomaram posse, sem ocupação imediata, de certas regiões pouco civilizadas..." $\mathrm{E}$ mais além acresce o internacionalista pátrio: "No número dos protetorados atuais, é costume incluir a Tunísia, o Anão, o Tonquim e o Comboja, países protegidos pela França, em virtude de tratados que datam de 1881 a 1884 . A sua situação, porém, pouco difere da de verdadeiras Colônias". (32)

\section{UNIÃO REAL E PESSOAL}

A União real, a pessoal e a incorporada são outros exemplos de formas estatais compostas que fogem também a uma fácil classificação e mesmo a uma análise estrutural precisa e eficiente. A União pessoal e a real, diz bem Queiroz Lima, "são formas de Estados essencialmente monárquicos". Ora, por serem formas de Estados em dependência absoluta de uma determinada forma de govêrno, é natural que, a pesar da denominação expressiva de união possam suscitar dúvidas quanto ao seu caráter federativo. E nêsse sentido Georges Scelle argumenta com vigor: "As Uniões pessoais não podem ser consideradas como fenômenos de federalismo, porque elas não derivam de uma associação voluntária de governos e de povos, mas de um jôgo quase automático da concepção patrimonial da soberania". (33) Elas não realizam "nenhuma ordem jurídica federal superposta às ordens estatais, mas uma espécie de paralelismo de ação governamental", cuja origem está situada na forma de govêrno, monárquica e hereditária.

A União pessoal é definida por Accioly com muita justeza: “é a reunião acidental e temporária de dois ou mais Estados independentes, sob a autoridade de um soberano comum. Por sua natureza êsse tipo de Estado composto quase só se pode conceber sob a forma monárquica. Dêle não existe mais exem-

(32) Hildebrando Accioly - Direito Internacional Público - São Paulo 1948, pág. 32/3.

(33) Georges Scelle - Op. cit., pág. 261 
plo". Constituem casos históricos e conhecidos as reuniões de corôas da Lituânia e Polônia (1386-1569), da Grã Bretanha e Hanover (1714-1837), da Holanda e Luxemburgo (1815-1890), da Bélgica e Congo (1885-1908).

A União real é conceituada também por Accioly como sendo "a reunião, sob o mesmo monarca ou chefe de Estado, de dois ou mais Estados soberanos, que conservam a sua plena autonomia interna, mas, por acôrdo mútuo, delegam a um orgão único os poderes de representação externa e, geralmente, fundem todos os interêsses comuns, no tocante às relações exteriores". (34) De acôrdo com essa definição verifica-se que tem motivos Kelsen para acreditar que "assim se esboça uma organização que tende a aproximar a União real da Confederação de Estados e, eventualmente, até do Estado Federal" (35) E Georges Scelle acresce: "A União real, que geralmente não se realiza senão entre dois Estados territorialmente contíguos, repousa sôbre uma base federativa, por que supõe uma solidariedade internacional". (36)

Não existem na atualidade tipos de Uniões reais, mas, podem ser lembrados os seguintes: Lituânia e Polônia (15691772), Suécia e Noruega (1814-1905), Áustria e Hungria .... (1867-1919). 0 último exemplo conhecido referia-se à Dinamarca e Islândia, união real que se constituiu em 1908 e foi dissolvida recentemente.

Alguns tratadistas distinguem ainda a chamada União incorporada, que segundo Darcy Azambuja, pode ser descrita como "a fusão de dois ou mais Estados independentes para formar um novo Estado, conservando aqueles apenas virtualmente a designação de Estados ou reinos". (37) Essa epígrafe refere-se ao exemplo sui generis da Grã-Bretanha, que é uma monarquia resultante da incorporação dos antigos reinos da Inglaterra, Escócia e Irlanda. Na realidade não há qualquer união,

(34) Hildebrando Accioly - Op. cit., pág. 28.

(35) H. Kelsen - Op. cit., pág. 97.

(36) G. Scelle - Op. cit., pág. 262.

(37) D. Azambuja - Op. cit., pág. 293 
porque os velhos reinos desapareceram, absorvidos por uma monarquia comum. Só a fôrça da tradição recorda, na vida protocolar interna, a origem remota dessa incorporação.

Sob o título genérico de Uniões de Estados estão colocadas, pois, três formas políticas que apenas mantém similitudes nominais: enquanto a União real descansa sôbre "base federativa" no dizer de Scelle, e pode ser considerada como "uma Confederação imperfeita" no sentir de Redslob, a que se denomina União pessoal em verdade não une os Estados que pretende, mas sòmente exprime direitos de sucessão a tronos eventuais e precários, criando situações por vezes extravagantes, como seja a de Jorge I, do Hanover, que herdou a corôa britânica e imperou sôbre os seus súditos sem conseguir aprender a falar a língua inglesa. Para entender-se com seu Ministério, o monarca germânico servia-se de intérpretes ou apelava para o latim.

\section{U. R. S. S.}

Analisados e definidos, como já foram, os tipos clássicos dos Estados compostos (Federação, Confederação, Uniões), cumpre aludir agora à existência de algumas entidades políticas contemporâneas que, pelas suas concepções estruturais sui generis, resistem a uma pronta e fácil analogia com as formas já previstas e descritas. Entre esta figura a Rússia Soviética, ou, numa denominação mais explícita, a "União das Repúblicas Socialistas Soviéticas".

A Rússia, doutrina muito bem Calmon (38) "declara-se uma federação original". As diversas Repúblicas são "federalizadas e soberanas nos limites da Constituição". Mas, acrescenta o mestre pátrio: "A novidade do sistema russo é a classificação das unidades federadas, em Repúblicas (nacionalidades) e regiões autônomas, partindo portanto da "realidade" étnico-histórica, qual a existência de verdadeiros Estados no Estado:

(38) Pedro Calmon - Op. cit., pág. 243. 
o direito de "desunião", que se contém no art. 4: - Cada uma das Repúblicas federadas conserva o direito de abandonar livremente a União".

Pela sua Constituição de 1923 a U.R.S.S. adotou um conceito de federalismo muito amplo e esboçou uma estrutura de União bastante ampla, com tendência para admitir o ingresso de nações mesmo estranhas ao seu núcleo regional. Daí a opinião manifesta por Queiroz Lima que desde a Constituição de 1923 deixou a Rússia de se considerar uma Federação Nacional, para formar uma União Internacional, com bases numa concepção de federalismo muito flexível. (39).

O que mais destôa na estrutura do 'Estado russo, que pela citada Constituição deu à União uma forma de República Federal, é, sem dúvida, o incomum "direito de retirada", concedido aos seus Estados-membros. Os tipos clássicos de Federações, como também os de Confederações, caraterizaram-se até agora pela perpetuidade dos laços federativos. A Rússia estatuiu novas bases federais, contrapostas aos velhos moldes jurídicos.

Mas não param aí as dissonâncias estruturais do Estado soviético. Num tipo comum de Estado Federal todos os membros manifestam idênticas constituições morfológicas e assumem perfeita igualdade de direitos em relação ao govêrno central. Dentro da U.R.S.S. as suas Repúblicas federadas não possuem a mesma forma, nem usufruem as mesmas regalias. Por exemplo: alguns de seus membros transparecem com Estados simples (Ucrânia, Rússia Branca, Turquemênia, etc.) outros como Estados compostos: a Federação da Rússia (abrangendo doze Repúblicas menores, inclusive a de Carélia, Tartária, Criméia, etc.), a Federação da Transcaucásia (formada por três Repúblicas, que são Georgia, Armênia e Azerbeijan). Também alguns dos Estados federados gozam de soberania exterior e personalidade internacional, outros não. No primeiro caso estão a Ucrânia e a Bielorússia, além da própria União Soviética. Por tudo isto, é evidente que a U.R.S.S. tem um cunho de "Fe-

(39) Queiroz Lima - Op. cit., pág. 307. 
deração de Federações", ou melhor - na ausência de uma forma equivalente a essa expresão - sua morfologia política apresenta maior semelhança com uma Confederação de Estados, ainda considerando-se esta categoria dentro de um conceito novo e ampliado.

\section{BRITISH COMMONWEALTH}

A curiosa morfologia política do Estado russo não é mais do que uma réplica republicana ao não menos singularíssimo e indefinível modêlo monárquico do Império Britânico, capaz, segundo Lord Balfour, de "desafiar qualquer classificação".

Na verdade, a "British Commonwealth of Nations" compunha-se após várias transformações (1926-1931), de seis membros principais, além de numerosas colônias espalhadas pelas cinco partes do mundo. Eram êles : o Reino Unido da Grã-Bretanha e Irlanda do Norte, o Eire (Estado Livre da Irlanda), o Domínio do Canadá, o Domínio da Nova Zelândia, a União Sul-Africana e a Federação Australiana. Êstes diversos Estados formavam uma vasta e íntima "Comunidade" alheios a qualquer lei constitucional ou orgânica, pois ainda na opinião de Balfour, tarefa inexequível e inútil seria dar uma Constituição ao Império, pela diversidade dos seus elementos componentes. Bastava uma convenção. E, de fato o Canadá, Austrália e União Sul-Africana eram Estados Federais, desde 1867, 1855, 1910, respetivamente. Mas êsse timbre federativo antecipava-se à própria autonomia, no caso da Austrália obtida só em . . 1901, por ato do Parlamento de Westminster. Ao lado das referidas Federações, o Agregado Britânico conjuga também formas estatais simples ou unitárias, como o Domínio de Nova Zelândia e a Irlanda.

Entre os anos de 1926 e 1931 os traços jurídicos mais salientes dessa Comunidade - uma reunião de membros com estruturas políticas dispares, mas tendo alguns traços comuns, eram, conforme ensina Orlando M. Carvalho, os seguintes: 
"I - todos reconheciam Jorge VI como seu rei; II - gozavam de igualdade de estatuto, não havendo subordinação de um a outro em assuntos nacionais ou internacionais; III eram livres e estreitamente associados como membros do Agregado Britânico de Nações." (40)

Dava assim essa composição política a idéia aparente de uma União pessoal ou real, porque ambas têm por base um regime monárquico, com identidade, ou melhor, com a simultaneidade de um mesmo soberano. Contudo, algumas transformações posteriores vieram desvirtuar essa primeira hipótese morfológica. Em 1937 o Eire (Irlanda) estatuia a forma republicana de govêrno. Desde 1921 já era conhecido como "Estado Livre da Irlanda", mas sem quebrar todos os elos com a Commonwealth. Por isso, a partir de 1937, o Rei, nas relações exteriores, tinha competência para agir em nome da novel República, nomeando por ela os agentes diplomáticos e ainda por ela assinando os tratados internacionais, que eram depois ratificados pelo govêrno republicano. Em vista dessa nebulosa situação de fato e de direito, onde se observa um parlamento republicano ratificar os atos internacionais praticados por um executivo monárquico, faz bem Orlando M. Carvalho em concluir: "O Eire é, pois, um reino republicano". (41)

Nova e extravagante transformação vem a se processar, em 1948, na estrutura do Império: o Eire a 20 de setembro dêsse ano volta a se proclamar República. A segunda proclamação não constituiu senão em romper os últimos liames com a Comunidade, isto é, passaram ao Presidente irlandês as prerogativas do Rei referentes às relações exteriores. Só na citada data, por consequência, é que o Estado Livre da Irlanda torna-se realmente livre, e a sua forma republicana faz-se efetivamente República.

Mas não param aí as dificuldades morfológicas. Outro "reino republicano" penetra na ossatura imperial: a fndia. Foi

(40) Orlando M. Carvalho - O Mecanismo do Govêrno Britânico - Belo Horizonte 1943, pág. 195.

(41) O. M. Carvalho - Op. cit., pág. 201. 
um membro da Comunidade que usufruiu uma personalidade internacional muito antes de obter a sua autonomia constitucional. De fato, já em 1919 a Índia assinava o Tratado de Versalhes e se considerava membro da Sociedade das Nações, figurando, pois, como verdadeiro Domínio inglês. Nas mesmas condições, em 1945, ingressava na ONU. Contudo, só em 1947 é que a India obtém o seu estatuto de Domínio, vale dizer, seus direitos de plena autonomia interna e independência externa. Mais ainda: nessa ocasião (1947) houve uma dicotomia de sua forma anterior, pois a inconciliável oposição entre seus habitantes (musulmanos e indús budistas) conduziu a política do Império a criar dois Estados distintos, o Paquistão e o Indostão. $\mathrm{E}$ ambos adotaram a forma de Repúblicas. Assim, pois, já é hoje um pouco difícil de explicar e de entender que, dentro da vasta Comunidade Britânica "o Rei é o símbolo da livre associação", ou melhor, que o Rei da Grã-Bretanha é, simultânea e separadamente, o mesmo Rei do Canadá, da Austrália, etc. Com duas Repúblicas incrustadas em seu organismo, certamente um Rei não pode mais ser "o símbolo vivente da União". Não se pode, porém deixar de reconhecer, como muito bem acentua Calmon, a existência de um forte "laço emocional do Império (o reconhecimento da corôa como sua expressão suprema) encarnado no Rei". (42)

O Indostão e o Paquistão substituem agora, dentro do Império, "o reino republicano" da Irlanda, absolutamente desligada de seus pares. Por isso com imensa razão, depois de seu minucioso estudo sôbre a estrutura íntima da Commonwealth, Orlando M. Carvalho conclui: "O Agregado Britânico de Nações constitui um novo tipo de associação de Estados, que desafia classificação e tem trazido farta canseira aos professores preocupados de dar uma categoria à invenção política dos ingleses. Não é uma Confederação, nem Federação, nem União de Estados". (43)

(42) Calmon - Op. cit., pág. 230.

(43) O. Carvalho - Op. cit., pág. 199. 


\section{UNIÃO FRANCESA}

A União Francesa, criada em 1946, apresenta-se também no cenário político da atualidade com forma original, desafiando fácil classificação. Surge do artigo 60 da nova Constituição, que declara textualmente: "A União Francesa compreende por uma parte a França metropolitana, os Departamentos e Territórios d'autre-mer e de outra parte os Territórios e Estados associados". Êsse artigo correlaciona-se com o preâmbulo constitucional, que também reza: "A França forma com os povos de ultra-mar uma União fundada sôbre a igualdade de direitos e deveres, sem distinção de raça nem de religião".

Não há dúvida, pois, que pela sua Carta Magna o vasto império colonial gaulês assumiu uma estrutura muito semelhante à da Comunidade Britânica, descentralizando-se politicamente, concedendo autonomias mais amplas aos seus antigos Protetorados na África e na Ásia. Izaga Burdeaux, Duverger e outros tratadistas contemporâneos nos descrevem essa organização atual e sui generis, sem precisar, contudo, a sua natureza jurídica, mal definida pela confusa e obscura epígrafe de "União". Ela compõe-se, com muita clareza, de quatro classes de entiddades associadas, sendo a primeira constituida pela França metropolitana. A segunda classe abrange os Departamentos $e$ Territórios de ultra-mar (as antigas colônias e Argel), que não são "membros", mas "departamentos administrativos" incluidos na República. Formam a terceira classe os Estados Associados, que eram os Estados Protegidos (44) como Marrocos, Tunísia, o Reino de Laos, etc. Enfim a última classe inclui os antigos "Mandatos" conferido à França pela Liga das Nações.

O esquema administrativo da União é, contudo, mais simples. Os seus órgãos diretivos são representados: I) Pelo Presidente da União Francesa, que é o próprio Presidente da Fran-

(44) Com pessimismo Luis Izaza anota que o Estado Protegido "não passa de um eufemismo" para indigitar o Estado vassalo, dentro do "amável consórcio da União Francesa". (Derecho Político - Barcelona 1952 - Vol. II). 
ça metropolitana. II) Pelo Alto Conselho, que é um órgão de tipo federal e consultivo. III) Pela Assembléia da União, órgão também consultivo, encarregado de estudar proposições de interêsse geral e composto de representantes da França (a metade) e dos Estados e Territórios Associados.

A União Francesa tem, portanto, um plano arquitetônico original, ao par de muitas particularidades dignas de realce. Por exemplo: enquanto a cabeça dêsse novel organismo político é uma Republica, de tipo unitário, parlamentar e laical, muito de seus membros são reinos do mais profundo cunho teocrático, como sejam Marrocos, Tunísia e Laos. E todos se agregam na soma de direitos e deveres do mesmo texto constitucional, que assim admite a inexplicável coesistência de governos republicanos e monárquicos, de Estado religiosamente neutro e de Estados confissionais, de sistemas democráticos aprimorados e de regimes aristocráticos hereditários e retrogrados, quais sejam os sultanados ainda não despidos das próprias tradições poligâmicas. Assim, pois, se a Irlanda e a Índia poderiam ser conceituadas, dentro da Commonwealth como "reinos republicanos", por antítese o Marrocos ou o Laos não desmerecem de ser chamados verdadeiras "repúblicas monárquicas", imersas na organização jurídica da Comunidade Francesa. Aliás, a União lembra muito de perto o sistema do Agregado Britânico, apenas com forma governamental oposta. Há um Presidente na posição em que êste coloca um Rei. E há também uma Constituição, onde os povos ingleses só colocaram uma Convenção. Por tudo isso, a União Francesa parece situar-se, morfològicamente, em posição intermédia entre os modelos da União Russa e do Império Britânico.

\section{UNIÃO HOLANDO-INDONESIANA E LIGA DOS ESTADOS ÁRABES}

0 fenômeno federativo evidencia crescer em intensidade no mundo moderno. Dois exemplos de Confederações embrio- 
nárias, que já se desenham com muita nitidez na atualidade e tendem ainda para uma forma evolutiva mais sólida no futuro são as da "União Holando-Indonesiana" e da "Liga dos Estados Árabes". A primeira, pelas suas origens e objetivos lembra muito bem a transformação do império colonial gaulês na atual "União Francesa". A segunda recorda o tipo anfitiônico da "União Pan-Americana" que, afinal, cimentou a presente "Organização dos Estados Americanos".

Colliard (45) nos transmite o texto do Acôrdo Provisório de 1946, pelo qual o reino europeu da Holanda procura estreitar os seus laços políticos federativos com suas antigas colônias do Oceano Pacífico. Assim, pois, deverá ser alicerçada a União Holando-Indonesa com os seguintes membros: uma parte integrante compreenderá os Países Baixos, Surinan e Curaçáo, outra parte integrará Java, Sumatra e Bornéo, isto é, os "Estados Unidos da Indonésia". Em acôrdo posterior, datado de 1949, já foi concedida pela Holanda à Indonésia a soberania sôbre suas possessões no extremo-oriente.

Pelo referido Acôrdo de Chéribon (1946), em seu artigo $7 .^{\circ}$ afirma-se que I) "A União holando-indonesiana possuirá seus organismos próprios e destinados a favorecer os interêsses comuns do Reino dos Países Baixos e dos Estados Unidos da Indonésia", II) “Êstes organismos serão constituídos pelos governos dos Países Baixos (monarquia) e dos Estados Unidos da Indonésia (república federativa) e, se necessário, pelo parlamento dêstes países". A seguir, pelo artigo $80^{\circ}$ dispõe-se que: "O Rei (ou Rainha) dos Países Baixos assumirá a chefia da União Holando-Indonesiana. Os decretos e resoluções concernentes aos interêsses comuns serão tomados pelos organismos da União em nome do Rei".

Ora, não fôsse o fato declarado de ser a Indonésia uma República, por certo a categoria morfológica de uma "União real" poderia estar, nêste caso, perfeitamente configurada. Mas com

(45) Claude-Albert Colliard - Droit International et Histoire Diplomatique - Paris 1948, pág. 32. 
a diversidade das formas de govêrno só o esbôço de uma Confederação apresenta-se aceitável.

A Liga dos Estados Árabes teve nascimento pelo Tratado do Cairo, a 22 de março de 1945. Constituiram-na, originàriamente, as Repúblicas da Síria, do Líbano e os Reinos do Iraque, Arábia Saudita, Transjordânia, Iemen e Egito. O Pacto está aberto à adesão de outros Estados árabes e independentes.

A finalidade da Liga é uma cooperação mais íntima entre os seus diversos membros nas questões seguintes: econômicas e financeiras, sanitárias, inteletuais e sociais, de nacionalidade, estradição e transportes. Seus órgãos administrativos são um Conselho (art. 3) e uma Secretaria Geral (art. 12). A séde permanente é no Cairo, mas o Conselho, cuja Presidência é rotativa, toma a decisão de se reunir em qualquer outro lugar. E êste órgão composto pelos representantes dos Estados associados, com um só voto por delegação. Reúne-se ordinàriamente duas vêzes por ano, em março e outubro.

Os artigos 5, 6 e 7 do Pacto constitutivo dão a impressão de representar a Liga um Super-govêrno confederal. Realmente aí se dispõe (art. 5) a supressão do jus belli: “É interdito o recurso da fôrça para a solução dos conflitos que possam surgir entre os Estados membros da Liga". Para resolver os litígios suscitados entre as partes, "a decisão do Conselho será obrigatória e executória". E mais: "As decisões de arbitragem e de conciliação serão tomadas por maioria de votos".

Ora, a finalidade primária das Confederações de Estados tem sido marcada pelos tratadistas como visando a manutenção da paz interna e, correlatamente, a defesa coletiva contra as agressões externas. 0 artigo 6 da Liga também previne: "Em caso de agressão ou de ameaça de agressão contra um Estado membro... poderá êste solicitar a reunião imediata do Conselho... que tomará as medidas necessárias para repelir a agressão".

Enfim as Confederações de Estados caraterizam-se ainda pelo "direito de nulificação", isto é, a possibilidade de qualquer associação opôr-se à decisão de um órgão central (Dieta ou Con- 
selho) quando não a tenha aceitado expressamente. Ora, pelo artigo 7 do estatuto árabe fica claramente previsto que "as decisões do Conselho tomados por unanimidade obrigam a todos os membros da Liga, e as que são tomadas por maioria não obrigam senão aos Estados que a aceitam".

Tudo isto muito aproxima a Liga Árabe da forma confederal adquirida pela OEA e pela ONU. Estas, contudo, além de possuirem órgãos diretivos mais aperfeiçoados e objetivos mais amplos são criações confederativas de base continental e mundial, respetivamente, enquanto a LEA lastra-se sobretudo na voz do sangue e seu condicionamento geográfico e secundário.

\section{O E A}

Incontestàvelmente o contôrno jurídico da Organização dos Estados Americanos - como o da Liga Árabe - é inspirado na morfologia política da antiga Sociedade das Nações. Esta primeira entidade internacional, embora não conseguisse sobreviver, legou o seu traço arquitetônico e a coordenação de seus órgãos diretivos como modêlo ou inspiração para as futuras entidades federativas de grande amplitude.

A OEA tem suas raízes remotas na bela e altruística filosofia da paz ameríndia, gradativamente evoluindo nas diversas combinações associativas do Pan-Americanismo, cujos precursores de maior projeção foram Henry Clay (1910), James Monroe (1823) e Simão Bolívar. Êste, em 1826, toma a iniciativa de reunir o Congresso do Panamá, visando nêle estatuir as bases de uma grande Confederação das Nações do Novo Mundo. Se a sua idéia fracassou por imatura, certo a primitiva semente não ficou perdida e mais tarde floresce numa sequência de Congressos continentais, entre os anos de 1847 a 1888, aproximando os povos e governos dêste lado do Atlântico. No ano de 1889 e na cidade de Washington reúne-se, enfim, a I Conferência Pan-Americana, por iniciativa de James Blaine. Normas jurídicas de vida comum e fraterna nascem ali dos tra- 
tados assinados. Firma-se o princípio da arbitragem para a solução pacífica dos conflitos. Mas o fruto de melhor sabor foi, sem dúvida, a criação de um tímido "Bureau Comercial das Repúblicas Americanas", com séde em Washington e destinado à modesta finalidade de estreitar os laços de amizade e comércio entre os Estados do nosso Continente.

0 progresso do Pan-Americanismo foi lento nos primeiros anos, mas sempre constante e seguro. Em 1901, na II Conferência, o primitivo "Bureau" comercial amplia sua competência e toma o título de "Bureau Internacional das Repúblicas Americanas". Seu funcionamento já inclui um Conselho Diretor. Na IV Conferência, em 1910, na cidade de Buenos Aires, o "Bureau Internacional" transforma-se numa organização administrativa mais sólida, que vem a ser denominada de modo mais adequado "União Pan-Americana". A VI Conferência, realizada em 1928 na cidade de Havana fixa, enfim, o estatuto jurídico e solene da "União", marcando uma estrada de mais amplos horizontes para a convivência pacífica e confederal dos Estados Americanos. Yepes assim nos fala a propósito: "Até essa data, a União Pan-Americana fundava-se num modus vivendi provisório. A partir de 1928, ela aparece como uma verdadeira instituição jurídica construída sôbre alicerces duráveis... A convenção de 1928 é para a União o que é para a velha Sociedade das Nações o convênio de 1919, isto é, representa o seu estatuto constitucional e a carta de suas atribuições" (46). Contudo o seu caráter era ainda apolítico e as suas funções muito cerceadas. 0 art. 6 do memorável pacto dispunha e prevenia que a União ou o seu Conselho Diretor " $n \tilde{a} o$ poderiam exercer nenhuma função política". Por isso Hélio Lobo ainda aludia a essa entidade como sendo um mecanismo destinado a promover "o entendimento continental para o bem comum". (47) E Yepes declarava: "O Pan-Americanismo não é outra cousa do que a consciência que têm tôdas as Repúblicas Americanas de constituir uma mesma família de nações".

(46) J. M. Yepes - Philosophie du Panamécanisme - Paris, 1945, pág. 182.

(47) Hélio Lobo - Q Pan-Americanismo e o Brasil - São Paulo, 1939, 
A Segunda Grande Guerra (1939-45) deu à União novo impulso evolutivo. Reunindo-se em 1945, no México, a Conferência de Chapultepec, destinada a estudar os problemas da guerra.e da paz, dela emergiram mais íntimos e duradouros postulados confederativos para os países continentais. De fato, o "Sistema Inter-Americano" ali criado já abrange inequívocas competências de caráter político. A "União Pan-Americana" passa a ser, de então, um "órgão central" do novel sistema, contendo uma "Secretaria" permanente. Mas a seu lado vão funcionar outros órgãos diretivos coordenados: 1) as "Conferências Internacionais Americanas", que traçam a orientação política comum das nações associadas. 2) as "Reuniões dos Ministros do Exterior", que resolvem os problemas coletivos e de emergência. 3) as "Conferências Especiais", que estudam questões de caráter técnico, 4) várias "Organizações Especializadas", que se destinam ao estudo continuado de assuntos de relevância econômica, cultural, sanitária, etc.

Com a evolução natural do Pan-Americanismo, com os preciosos exemplos da SDN e da ONU - duas confederações ecumênicas - com os antecedentes mais recentes da Conferência de Petrópolis, em 1947, que aprovou o Tratado de Assistência Recíproca em caso de agressão extra-continental, estava preparado o ambiente para, no rincão inter-americano, ser lançada a base de uma vasta Confederação de Estados, talvez como a sonhara Bolívar em 1826. Realmente, a IX Conferência de Bogotá, em 1948, aprovou a carta constitutiva da "Organização dos Estados Americanos". Fato digno de registro é que a essa reunião internacional compareceram, além da totalidade das nossas Repúblicas, mais as delegações da ONU e da UPA, como observadoras.

A OEA tem como membros os 21 Estados das duas Américas. Não há ingresso de novos associados, salvo futuras formações federativas regionais. Curioso é o fato de existir em Washington, na séde da Organização, um assento vago (22. $\left.{ }^{\circ}\right)$ e reservado ao Canadá. Assim, se por ventura êsse membro da Commonwealth vier no futuro a desligar-se das entidades bri- 
tânicas já tem assegurado o seu ingresso, por longínqua antecipação, na OEA, que assim evidencia e previne as bases de sua vocação regionalista.

Os órgãos diretivos da Organização Americana são: 1) as "Conferências Inter-Americanas" (art. 33 da Carta), que é seu órgão legislativo, decidindo, por maioria de votos da ação política dessa entidade, e incidindo, portanto, diretamente sôbre as soberanias estatais de seus membros. 2) a "Reunião de Consultas dos Ministros de Exterior" (art. 39), que é órgão consultivo para problemas de urgência. 3) o "Conselho" (art. 48), que é um órgão executivo. 4) a União Pan-Americana (art. 78), que é o órgão administrativo e compreende um "Secretario Geral". Completam a Organização as "Conferências e os Organismos Especializados" cujas funções são técnicas e complementares dos já referidos.

Têm pois razão Quintana e Schaw em afirmar, sem temor, que "a OEA é uma Confederação de Estados" (48), mas carecendo provisòriamente de existência legal porque a maioria de seus membros ainda não ratificou o respetivo tratado. Em verdade, pela sua carta constitutiva, de 1948, a OEA demonstrou possuir: a) personalidade internacional, b) capacidade jurídica e privilégios diplomáticos, c) direito de legação, d) direito de paz e guerra, e) direito de negociação. Ora, jus legationis, jus tractuum e jus belli são as principais competências das entidades políticas soberanas que denominamos Estados.

\section{ONU}

A entidade política de máxima extensão na atualidade é a Organização das Nações Unidas. $\mathrm{E}$ à imensa amplitude de sua jurisdição - Civitas Gentium Maxima - corresponde a importância indiscutível dos seus propósitos e atribuições: "manter a paz e a segurança internacionais", "preservar as ge-

(48) Morena Quintana e Bollini Schaw - Derecho Internacional Publico - Buenos Aires, 1950. 
rações vindouras do flagelo da guerra", "reafirmar a fé nos direitos fundamentais do homem", "promover o progresso social e melhores condições de vida dentro de uma liberdade mais ampla". (49)

Nasceu a ONU da Conferência de São Francisco, onde, em 1945, a 26 de junho, cinquenta Estados assinaram a sua memorável Carta Constitucional, ao término da maior guerra que já incendiou o pequenino mundo em que vivemos. Prepararam e possibilitaram a sua estruturação várias conferências internacionais, especialmente a de Dumbarton Oacks, onde se redigiu o ante-projeto dêsse futuro pacto multilateral que é hoje a Carta das Nações Unidas. Contudo, a pesar de não ser a ONU uma simples transformação da antiga Liga das Nações, nem mesmo a sua sucessora, mas uma entidade nova e desobrigada de qualquer compromisso anterior, é evidente que os órgãos e as funções das duas sociedades políticas internacionais têm semelhanças profundas. Não pode, assim, haver dúvida em que a velha Liga de Genebra foi a inspiradora direta da novel Organização de Lake Success. A morfologia de uma e de outra são afins e, por consequência, a análise estrutural que se intente para a mais recente dispensa rememorações alongadas e digressivas para a anterior.

O capítulo III da Carta de São Francisco indica como órgãos fundamentais das Nações Unidas os seguintes: Assembléia Geral, Conselho de Segurança, Conselho Econômico e Social, Conselho de Curadoria, Côrte Internacional de Justiça e Secretariado. Pelas atribuições específicas de cada órgão, sua composição e funcionamento, verifica-se que os poderes legislativos, executivos e judiciários acham-se ali perfeitamente divididos e coordenados, como se tornou clássico no mecanismo do Estado Moderno. O próprio poder administrativo, que já se delineia como um quarto poder independente nas modernas concepções doutrinárias do Direito Público, tem expressão, dentro

(49) Dep. de Inform. - Carta das Nações Unidas - Nova Iorque, 1948 - Preâmbulo. 
da ONU, na série de atribuições concedidas ao Secretariado, ao Conselho Econômico e Social e ao Conselho de Curadoria.

A natureza jurídica da ONU - como todos os grandes temas jurídicos - é controversa. Por muito tempo ainda permanecerão os debates a êsse propósito, oscilando os tratadistas em considerá-la entre as categorias de uma simples associação pacífica de caráter universal, mas sem profunda penetração na vida orgânica e intangìvelmente soberana dos seus Estados membros, e a categoria mais alta de uma verdadeira Confederação Mundial, orientando e vincando tôda ação política internacional com os traços marcantes de um "Super-Estado", no diminuto orbis terrarum em que a interpendência cultural e econômica dos povos é necessária e inadiável. Em livro anterior (50) já tivemos oportunidade de preferir a segunda hipótese. Escrevemos então: "A ONU, estruturalmente considerada, é uma Confederação de Estados, de caráter ecumênico, isto é, uma ordem jurídica de máxima superposição".

Realmente esta é a preciosa lição de Delbez: "Dentro do terreno dos conceitos jurídicos, somos conduzidos a definir a ONU: uma Confederação de Estado com território descontínuo e vocação universal". (51) E como o professor de Montpellier, também o mestre da Universidade de Strasbourg, Robert Redslob reafirma essa opinião: "Reconhecemos que o edifício de Genebra possuia todos os traços distintivos de uma Confederação de Estados... Não era uma Confederação egocêntrica, em oposição a outras entidades... mas um sistema de solidariedade geral que tendia para a universalidade. As mesmas considerações valem para a ONU... Entende-se por Confederação um sistema contratual durável entre vários Estados, tendo por fim salvaguardar a paz entre os seus membros". (52)

(50) José Nicolau dos Santos - ONU - Curitiba, 1952, pág. 208.

(51) Louis Delbez - Droit International Public - Droit Général et Droit Particulier des Nations Unies - Paris 1951, pág. 118.

(52) Robert Redslob - Traité de Droit des Gens - Paris, 1950, pág. 129. 


\section{AS MODERNAS CLASSIFICAÇõES MORFOLÓGICAS}

Frente a tão complexas e dispares entidades poltíicas (ONU, OEA, Commonwelth, União Francesa, URRS), que o Direito Público contemporâneo viu nascer e vicejar à margem de seus cânones ultrapassados e envelhecidos, não é fácil aos juristas a escolha do criterium que deve presidir uma racional classificação morfológica dos Estados. Mac Iver, talvez desalentado de encontrar uma solução satisfatória, escreve e previne: "Os Estados, como outras formas sociais, explícita e finalmente não se dividem em gêneros e espécies. A passagem de um tipo para outro é quase imperceptível, não só na História como no presente. Os tipos sociais não têm a fixidez relativa das formas orgânicas". (53) Todavia, o Professor da Columbia oferece uma interessante classificação dos Estados, introduzindo a fórmula louvável de coordenar vários critérios conexos. Dá preferência às diferenciações que decorrem dos regimes políticos (Democracia, Oligarquia, Monarquia), conjugadas às formas de govêrno (República e Monarquia - Presidencialismo e Parlamentarismo) e, enfim, ao aspecto morfológico (Estado Unitário, Federação e Confederação). E com êsses elementos, simultâneamente aproveitados, elabora uma das mais longas e completas classificações das formas estatais.

Quintana e Schaw (54) também apelam para critério duplo: a hierarquia governamental e a forma política. Os tratadistas argentinos vêem, assim, dois grupos de Estados: I) os independentes, que se distinguem em simples e compostos (êstes com seus diversos tipos de Uniões de Estado) - II) os dependentes, onde se incluem os Estados Protegidos, Vassalos, Domínios e Mandatos.

Maciejewski (55) prefere uma visão evolutiva das associações humanas: I) as associações naturais (famílias, nacio-

(53) R. M. Mac Iver - O Estado - São Paulo, 1945, pág. 247

(54) Morena Quintana e Bollini Schaw - Op. cit., pág. 94.

(55) Casemir Maciejewski - La Théorie du Droit - Paris, 1931, pág. 73. 
nalidades, etc.) - II) as associações políticas de uma só nacionalidade (tribo, principado, Estado) - III) as associações políticas de várias nacionalidades (Estados compostos, coloniais, etc.) - IV as alianças futuras de Estados (comunidade e associações internacionais). 0 objetivo dessa classificação é fugir à dificuldade inicial de predeterminar se alguns Estados compostos (as Confederações, por exemplo) devem ou não ser considerados como verdádeiros Estados. Para Maciejewski, no "organismo político" - uma expressão mais ampla - inclui-se também o Estado.

Georges Scelle (56), no esfôrço de distinguir as formas de Estado per genus et differentiam, prefere descobrir vários tipos de "sociedades internacionais" circundando a categoria, presupostamente reconhecida, da sociedade política estatal. Para o Professor de Paris existem: I) as sociedades inter-estáticas, tais como a "Sociedade Global" ou "Comunidade do Direito das Gentes" (anterior à SDN ou a ONU) ainda não organizada, mas criando relações internacionais lastradas sôbre costumes e tratados. Há, no caso, uma ausência de órgãos político-administrativos comuns. II) as sociedades super-estáticas, já organizadas e mesmo hierarquizadas. Surgem estas da natural expansão do "fenômeno federativo", pois o Estado é evidentemente "uma ordem jurídica de superposição". O Estado Federal é a expresão mais aperfeiçoada da sociedade super-estática. Contudo, naquela categoria ainda se incluem outras formas mais ampliadas, constituindo verdadeiras "federações de federações". A SDN (como a ONỤ), dispondo de órgãos administrativos e deliberantes comuns, representa igualmente uma realização do federalismo ecumênico. III) as socíedades extra-estáticas, que têm finalidades próprias e transcendentes da órbita estatal como nos dá precioso exemplo a Igreja Católica.

Guido Gonella e Maurice Duverger adotam, para estudo da tumultuosa morfologia política dos tempos atuais, esquemas semelhantes ao de Scelle, mas com algumas divergências. Duverger (1), por exemplo, admite: I) os sistemas jurídicos in-

(56) Georges Scelle - Droit des Gens - Paris, 1932 - Vol. I, pág. 50, 58. 
tra-estáticos (família, sindicatos, associações diversas) - II) os sistemas jurídicos supra-estáticos (decorrente das composições federativas estatais, inclusive SDN e ONU) - III) os sistemas jurídicos extra-estáticos (como sejam as associações privadas internacionais, a União Postal universal, etc.).

Mais analítica e interessante é a classificação de Gonella, que nos diz: "Considerando quem é o artífice da sociedade (a pessoa) e qual o critério orientador da ordem social (o fim), podem considerar-se as várias sociedades como anéis concêntricos: a pessoa ocupar o centro; o primeiro anel é a sociedade familiar; o segundo, a sociedade estatal; o terceiro, a sociedàde internacional. Domus, Urbs, Orbis: são êstes os tipos fundamentais de sociedades naturais a serviço do homem (afora a Igreja, que é uma Sociedade Sobrenatural), espaços vitais nos quais se exterioriza e se expande a vida religiosa, moral, jurídica, política e econômica da pessoa". (58) o jurista italiano, enfim, oferece uma classificação das várias formas de associações humanas, relacionando-as com o Estado: I) a sociedade pré-estatal (a família) - II) a sociedade para-estatal (a associação de classe, como a corporação, o sindicato, etc.) III) a sociedade estatal (o Estado, com suas várias formas) IV) a sociedade inter-estatal (a sociedade dos Estados) - V) a soicedade super-estatal (a Igreja).

Redslob, enfim, distribui as entidades políticas federadas em duas classes: I) tipos de subordinação, subdivididos em a) Estados Federais (Brasil, América, Argentina, etc.) - b) Estados com sujeição (Protetorados e Vassalos, Dantig e Trieste, etc.). - II) tipos de coordenação, subdivididas em a) Confederações (Germânica, Suiça, SDN, ONU, etc.) - b) União Real (Suécia, Noruega, etc.) — c) Império Britânico.

(57) Maurice Duverger - Droit Constitutionnel et Science Politique Paris, 1948, pág. 21.

(58) Guido Gonella - Bases de uma ordem Social - São Paulo 1947, pág. 92, 95.

(59) Robert Redslob - Op. cit., pág. 130. 


\section{CONCLUSÃO}

Recolhidos os ensinamentos dos mestres e confrontadas as suas principais divergências doutrinárias, não nos esquivamos ao desejo de tentar um ordenamento esquemático das formas Estado, a pesar dos empeços quase intransponíveis que o assunto oferece. Em primeiro lugar, presupondo um conceito mais ou menos pacífico da sociedade estatal, cumpre distinguir as que com ela se relacionam ou interferem. Nestas condições teremos: I) as sociedades pré-políticas, que antecedem o Estado e por vêzes lhe dão origem (família, clan, tribo, nacionalidade) - II) as sociedades politicas, onde se incluem as formas estatais simples (Polis, Civitas, Estado unitário) e as compostas (Estado Federal, Confederação e União de Estado) - III) as sociedades intra-políticas abrangendo sindicatos, corporações e demais associações subordinadas à ordem jurídica estatal. IV as sociedades supra-politicas, cujos fins e cujas fôrças de coesão transcendem o âmbito jurisdicional e administrativo dos Estados, a êles não se subordinando, mas com êle paralelamente interferindo nas atividades coletivas ou orientando a vida moral das demais sociedades (por exemplo: a Igreja, a Civitas Gentium Maxima ou Sociedade Internacional não organizada). - V) as sociedades extra-políticas, que realizam alguns fins comuns e conjugados dos Estados dentro da Sociedade Internacional (tais como a Cruz Vermelha, a União Postal Universal, etc.). São elas as várias associações filantrópicas, uniões administrativas, sociedades culturais, centíficas, artísticas, etc., que, simultâneamente, nem se subordinam a um Estado determinado nem também se sobrepõem à qualquer ordem jurídica nacional. 
Mais particularmente, com referência às formas dos Estados (sociedades políticas), uma classificação racional terá por base o grau de liberdade ou autonomia político-administrativa com que êles podem agir dentro da comunidade internacional. Outros critérios serão depois invocados para a complementação das diferenças, inclusive os sistemas de govêrno, pois só êstes podem determinar os casos especiais da União Real e da pessoal. O esquema anterior, atendendo à lição de Burdeau "o Estado simples é o protótipo do Estado" - procura abranger as diversas manifestações morfológicas das sociedades políticas, tanto as mais antigas como as mais modernas.

Há, evidentemente, nesta classificação alguns artifícios necessários. Em primeiro lugar deixamos à margem o problema, não menos trabalhoso de predeterminar a natureza estatal ou simplesmente associativa da Confederação de Estados. Em segundo plano, também aceitamos a possibilidade de ampliar o conceito de Confederação, como já previa Spiropoulos e como a realizaram Quintana, Schaw, Redslob, Kraus, Verdross, Niemayer e outros tratadistas que viram na antiga SDN e vêem na atual ONU um tipo ecumênico de Confederação de Estado. Como êsses organismos poltíicos de cunho universal, também a Organização dos Estados Americanos (OEA) é tida na categoria de uma Confederação pelos melhores autores. Ainda com maior facilidade e melhor nitidez é possível divisar na Comunidade Britânica, na União Francesa ou União Russa tipos de associações políticas confederativas. Commonwealth e URRS são, na verdade "federação de federações", apenas com menor amplitude, isto é, são Confederações regionais ou nacionais de Estados. Scelle, por exemplo, assim julga e indigita a primeira: "Para nós, o caráter federal da Commonwealth subsiste. Mas de que categoria?... Pràticamente pouco importante é a cogitação. Deve-se todavia, do ponto de vista teórico, admitir-se que se trata ainda de uma Confederação trés reâchée". E alinhando argumentos dos mais ponderáveis o professor de Paris vê-se capacitado para concluir: "Os membros da Commonwealth são Estados... Quanto ao seu caráter de Confederação, determina-se por eliminação. Não se pode falar de União pessoal, por 
inexistência dos elementos patrimoniais e transitórios desta forma social inter-estática... Pelos mesmos motivos não se trata também de União real. . Resta então a forma confederal. Se ela apresenta aqui caracteres particulares é em razão de suas origens. Provém do unitarismo. Os Domínios foram colônias antes de adquirir autonomia constitucional... Conheceram depois um processo de segregação". (60) Para GeorgesScelle ainda a velha Sociedade das Nações transparecia como sendo "uma federação de federações, que equivale a uma Confederação trés lâche".

Ora, na pobreza atual do nosso vocabulário jurídico - político não é possível desprezar o têrmo "Confederação", tornando-o inusitado sòmente porque alguns tipos confederativos clássicos - tais como as antigas Confederações Germânicas, Suiça e Americana - já desapareceram na História transformadas em Estados Federais. E' sempre oportuno lembrar a advertência de Burdeaux: "Em Ciência Política uma definição não pode exprimir senão tendência". (61) Um novo e mais lato conceito de Confederação está bem impresso na lição de Calmon: "Distingue a Federação a homogeneidade: todos os Estados são governados de modo análogo. A Confederação ao contrário, é a união de reinos, principados, ducados, cidades livres ou repúblicas". (62) Ora, é precisamente êsse aglomerado de reinos e repúblicas, essa estonteante fusão ou justaposição de sistemas governamentais antagônicos que presenciamos constituir o estêio vertebral de algumas entidades polítcas contemporâneas: a ONU, a Comunidade Britânica ou a União Francesa. Dessas e de outras construções jurídicas - por certo incomuns e infladas em suas estruturas internas - projetam-se naturalmente formas exteriores anômalas e desproporcionais, que não mais se casam aos figurinos usados até hoje e, assim, vão relegando as velhas nomenclaturas morfológicas para o rol das causas imprestáveis ou desajustadas.

(60) Georges Scelle - Op. cit., pág. 245, 246.

(61) Georges Burdeaux - Traité de Science Politique - Paris, 1949, Vol. II, pág. 130.

(62) Pedro Calmon - Op. cit., pág. 


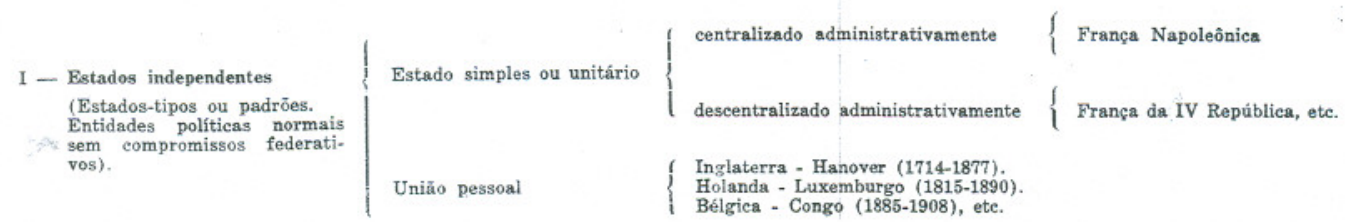
II - Estados dependentes
(Sub-Estados. Entidades poli-
ticas infra-estatais ou hieràr-
quicamente subordinadas). Estado vassaio $\{$ Rumânia, Sérvia (até 1878), Bulgária (1878-1909). Estado protegido $\quad($ Reino de Cambodge (1884-1946). Domínio $\{$ Canadá, Austrália, Nova Zelândia, ete. (até 1930). Mandato A $\{$ Iraque (1919-1930), Síria e Líbano (até 1941), Transjordânia (até 1948).

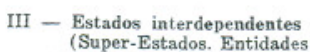
(Super-Estados. Entidades po-
líticas sobrepostas ou hieràrquicamente superiores).

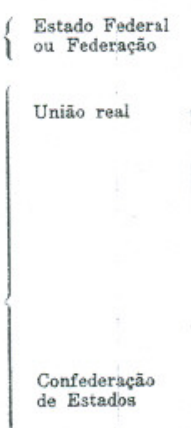

federalismo coordenador

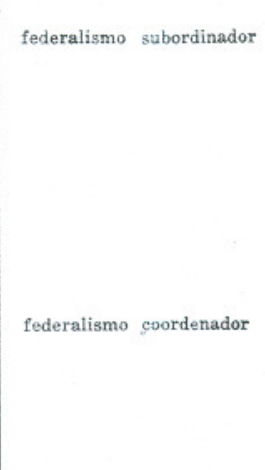

Brasil,
Estados Unidos da América

Suiça, ete. Austria - Hungria (até 19ís), etc. tipos clássicos
ou históricos $\left\{\begin{array}{l}\text { nacionais } \\ \text { ou regionais }\end{array}\right.$ Estados Un. Amer. (1777-1787). Conf. Germânic Conf. Alemanha Norte (1866-1871). Conf. Helvética (até (1848).

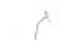

tipos modernos nacionais
ou regionais
continentais
universal

Commonwealth União Francesa Liga dos Estados Árabes OEA ONU 